\title{
THE CULTURE AT THE BEGINNING OF THE NEW MILLENNIUM FROM THE PERSPECTIVE OF „THE SURVIVOR": A FUNDAMENTAL BREAK IN THE SECRET CODE OF AESTHETICS. UKRAINIAN EXPERIENCE ${ }^{*}$
}

\section{Humeniuk Tetiana}

\section{INTRODUCTION}

Global transformations in the modern world are affected by processes that take place in the post-Soviet space because they have formed a unique type of culture, which researchers define as a product of trauma caused by the long internal colonization of the people mentality.

At the turn of the XX - XXI centuries, like other boundary situations in the history of society, the perception of the past is sharpening, and the $\mathrm{XX}$ century, especially its last decades, is perceived as not only the end of the century but of the entire historical epoch, in fact, of all modern times. This situation actualizes the recollections and comparisons with the beginning of new milestones in the history of mankind, especially the views, concepts of famous thinkers, scientists, artists who felt the dynamic of the historical process. It is not about the echo of times, not in a chronological sense. Obviously, in our time it is worth resorting to the verification of some beliefs views, concepts, theories, to compare them with the present reality, because some of them, having flourished, denied, even forgotten, become relevant again. One of these is the concept of catharsis, which was substantiated in ancient aesthetics. It was organically incorporated not only into the scientific circulation but also widely used to characterize the everyday life realities of modern society, influencing the criteria for the evaluation of art. These issues are especially relevant in scientific research with the beginning of the active development of society in the periods of post-: post-industrial, postmodern, post-historical...

\footnotetext{
* "The survivor" - Eng. -“a person who survived", "victim".
} 


\section{1. "Traumatized" as a Symptom of Modern History:}

\section{From the Beginning of the XX to the Beginning of the XXI Centuries}

In the history of Ukraine, in particular, during the $\mathrm{XX}$ and XXI centuries, there were many tragic events that formed the traumatic experience of society: World War I, Civil War, collectivization, deportations, Holodomor 1932-33, Stalinist terror of the 30's and the postwar years, the Second World War, the Famine of 1947, the collapse of the Soviet Union, the Chernobyl disaster, the Maidan, the annexation of the Crimea, the war in the Donbas. It is important to understand the nature of their cultural, social, psychological collective and individual transformations, to develop strategies for working with such experiences, including psycholinguistic ones, in order to further overcome its negative consequences.

The theoretical discourse on historical events that gave rise to collective trauma is one of the elements of the cultural paradigm that articulates this trauma and enables its subject to overcome the effects and consequences of the experience. Besides, it at least draws the attention of the society to the acquired tragic experience, which causes deep social and psychological traumas, requires elaboration and reflection. The lack or insufficiency of appropriate analytics on the causes and effects of such injuries is dangerous because the pain experienced is chronic and transmitted to the next generation. Therefore, it becomes necessary to consider a rather wide range of interdisciplinary studies on the concept of trauma, to analyze the formation of different types of narratives about the collective traumatic experience acquired by Ukrainian society at the beginning of the 21 st century.

The analysis of interdisciplinary studies of the concept of trauma, the involvement of theoretical tools of multi- and interdisciplinary text "trauma studies" provided an opportunity to reveal the essence of different types of narratives about the collective traumatic experience acquired by Ukrainian society at the beginning of the 21 st century. First of all, it should be noted that the word "trauma comes" from the ancient Greek $\tau \rho \alpha \nu \mu \alpha$, that is, "wound", and, according to most researchers, the concept of "trauma", is a paradigmatic characteristic not only of the history and culture of the XXI century but also of the XXI century beginning. Therefore, the sensitivity of society to the topic of violence, theorisation and detailed categorization of these phenomena, or, conversely, the inability to execute it (in cases of extreme violence that destroys any category), only intensify with the deepening of the modern 
traumatic experience of humanity. As political rhetoric becomes more and more biopolitical, a new conceptual paradigm is emerging in relation to the trauma, according to which societies and politics, religion and law, medicine and psychoanalysis, science and the arts can be in new relationships.

The theoretical concept of our study is based on the work of Tamara Hundorova, which emphasizes the need: “... to speak and study the traumatic places of Ukrainian culture of the beginning of the $21 \mathrm{st}$ century - post-colonial ressentiment, the break of generations and the memory of the past in modern post-Soviet times, in the artistic culture in general - T. H.), the break of high and popular culture, a new understanding of the classics, kitschization as a way of reception of traumatic experience, as well as Chornobyl - an event that has largely defined and shaped initial thinking in Ukraine."1 The indisputability of this opinion is confirmed by the unique artistic phenomenon of 2019, which shocked the whole world - the American mini-series about the Chernobyl disaster. This film makes the viewer feel the horror, despair, helplessness, confusion and tragic hopelessness of the people who directly experienced this tragedy. All those involved - politicians, officials, station workers, in a critical state of radiation poisoning, concealed the real state, produced great lies to cover up the terrible scale of the catastrophe.

The film "Chornobyl" is not perceived as an accusation of the Soviet system or a campaign against the use of nuclear energy. It focuses on the trait that is common to all people on their ability to solid lie and that it revolves not only in the scale of geopolitics but also in personal relationships (and it is the most important!). "Chornobyl" touches universal values... This film is not only about Chernobyl but also about us, - Erlingur Einarsson writes in his review of the series. ${ }^{2}$

Socio-psychological scientific studies of world tragedies of this magnitude began in the 1970s, the authors of which focused on these socalled post-traumatic stress disorders. They identified and compared links between the psychological reactions of those who went through the

1 Hundorova T. (2013) Vid avtora [From the author]. Tranzytna kultura. Symptomy postkolonialnoi travmy [Transit culture. Symptoms of postcolonial trauma]. Kyiv: Hrani-T, p. 20.

${ }^{2}$ Einarsson E. (2019, June 06) Chernobyl review: "Stunning and shattering in equal measure". Retrieved from https://www.gamesradar.com/chernobyl-hbo-review/ (accessed: 19.06.2019). 
Vietnam War, who survived the Hiroshima bombing and Nazi torture, survived the Holocaust or slavery and segregation among AfricanAmerican identities. Researchers have developed a new, important category for our time - the survivor: "the one, who survived", "injured», "victim". 3

In particular, Robert Jay Lifton writes in his books about wars, social and environmental disasters, first and foremost as the collision of a person with death. He tries to spread the suffering of the victims to the outside world, because the destructive potential of these disasters means that "we all belong to those who survived after Hiroshima," and let's add: after the Holocaust, after colonialism, after Chernobyl, after the Maidan, after "the war". 4

The prolonged impact of traumatic experiences on the individual and the collective consciousness gives rise to a feeling of fear, a deep inner vulnerability at the individual and collective levels, dividing life into "before" and "after". The theory of national trauma by Arthur Neal ("National trauma and collective memory: major events in the American age") is convincing and important for considering the problem raised, according to which decisive factors for turning any event into a national trauma are its deviation from the "norm", from the usual state of things, radical changes in society that "affect all major subgroups of the population." In this case, the crisis that actualizes national trauma can be acute, caused by an aggressive act or catastrophe, or chronic, prolonged.

These reflections are directly related to the situation in Ukraine. In particular, T. Hundorova notes that Ukrainian society is in a long process of exiting the state of enslavement - political, social, economic, mental. It characterizes the culture of Ukraine as a product of trauma, defining it as transit.

Due to the tragic events of the late twentieth - early twentieth centuries, Ukrainian society is experiencing a state of transition (transit Latin trans name - "through", "across" and the verb "trans+ire" -

${ }^{3}$ Lifton R. (2005) Tehnologija "promyvki mozgov": Psihologija totalitarizma [Brainwashing Technology: The Psychology of Totalitarianism]. St. Petersburg: Prajm-Evroznak.

${ }^{4}$ Lifton R. (2005) Tehnologija "promyvki mozgov": Psihologija totalitarizma [Brainwashing Technology: The Psychology of Totalitarianism]. St. Petersburg: Prajm-Evroznak.

5 Neal A. G. (2005) National Trauma and Collective Memory: Extraordinary Events in the American Experience. Armonk, New York: Routledge, p. 10. 
"pass") into a new being of culture. By the way, the communicative patterns inherent in an individual trauma differ from those which are inherent in a national, collective trauma: If individuals reluctantly transfer negative or disturbing information, then traumatic the event of national scale quickly extends, bearing mass experience as a result of which there is an effect of mutual "attraction": individuals are grouped to have an opportunity to respond to the tragedy in a certain way. Also, if individual reactions to traumatic experiences can be as varied as possible, sometimes even opposite, then “... collective responses are standardized in the process of the formation of myths and legends aimed at defining the moral boundaries of society." 6 .. In this way, we reform society as a moral community and create sacred symbols capable of shaping national identity.

One of the important problems in the process of shaping modern Ukrainian society is the lack of a unifying myth that would direct present contradictory, sometimes tragic, transgressive processes in society. For example, in different regions, social groups acquire a rather arbitrary interpretation of the events of World War II, the Soviet past of Ukraine, the modern movement towards European iteration, and many other phenomena of social life. Such a contradiction is inherent in the Ukrainian mentality, it reflects the state of Ukrainian consciousness, which has been affected by the traumatic processes that determine the present and affect the future of the country.

As a result of the Chornobyl disaster, Ukraine has emerged as a deeply traumatized social space that has signalled to the world a new state: the entry into the zone of a new culture of the humanity of the third millennium. As A. Neal points out: “...trauma often frees up the social system: by shedding the old order, it reveals new opportunities and innovations when the very fact of a subversive event can testify to the ineffectiveness of the social system." Playing this tragedy on-screen made an impression of amazing power - today, Ukraine is perceived in the world as a unique space in which the collective traumatic experience, important to all humanity, as a warning and a caution, is concentrated.

The Chornobyl series drew attention to the problem of "memory recovery". Screenwriter Craig Meisin had collected books about Chornobyl that helped him work on the film. Among them are many

${ }^{6}$ Neal A. G. (2005) National Trauma and Collective Memory: Extraordinary Events in the American Experience. Armonk, New York: Routledge, p. 20. 
Ukrainian editions, including: "Chornobyl: Documentary Story" ("Dnipro", 1989) by Yuri Shcherbak, "Chornobyl Notebook" ("Dnipro", 1990) by Grigory Medvedev, "Outland, or Walk into the Zone" (NoraPrint, 2015) Markiyana Kamysh, "KGB Chornobyl File". (Compiled by SBU Sectoral State Archives, Institute of History of NASU, Ukrainian Institute of National Memory, 2109). It is fundamental for the authors and editors of these books to realize that victims are not only remembered for the past, but are still living this event, so it is always upto-date. "Traumatized ... turn into a symptom of a story that they are unable to fully master.",

Ukrainian society has yet to realize its tragic losses, unite so that the individual does not fall into "...the dead-end of endless melancholy, inability to grieve ..." manifested in the compulsive re-actualization of experience, in the interference of the past in the present and in the present time. Thus, awareness of the tragic experience as a kind of nonhealing "wound" on the cultural fabric of society is important because it has powerful inertia, acquiring the "symbolic expansion" and universalization necessary to understand it. This leads to a disturbance of the world of senses and meanings that continues in the time-space of culture, broadcasting from generation to generation.

Both the word "Holocaust" (in Hebrew "Shoa" - "catastrophe", "disaster") after the show of the same name on American television (1978) and the words "Chernobyl", "Maidan" "war in the Donbas", "annexation of the Crimea" have become a kind of metaphor; they not only express the tragedy of the historical experience of the Ukrainian people but also warn humanity against threats in the way of its further cultural progress. So, not only do we "look" into our past and present, but the whole world takes into account our historical experience. After all, this is the change of world narratives in the context of "transculturalism" at the beginning of the 21 st century, when Ukraine, with its extremely complex and multi-vector social and cultural progress, creates a completely unique, model of national life.

7 Caruth C. (ed.) (1995) Trauma: Explorations in Memory. Baltimore: Johns Hopkins University Press, p. 5.

${ }^{8}$ Alexander J. (2013) The Meanings of Social Life: cultural sociology [Smysly soczialnoj zhizni: kultursocziologiya], (trans. G. K. Olkhovikova). Moscow: Praksis, p. $102-103$. 


\section{Contemporary Art Sub Specie Theory of Catharsis}

In today's medialized world, there is a unique opportunity to "evoke a sense of simultaneity of historical experience", "a sense of empathy with experience" in different peoples, societies and categories of population, enabling a special type of shared, social autobiographical memory of events to be formed ${ }^{9}$.

At the beginning of the new millennium, the cultural memory of humanity is first and foremost actualized. The process, according to French historian Pierre Nora, is truly global, worldwide ${ }^{10}$. It is predicated on specific historical reasons: the first of these is the acceleration of history, which destroys the integrity of historical time, that beautiful and clear straight line that combined the past with the present and the future. The historical disavowal of models of ideas such as restoration, progress, and revolution have made it impossible to foresee the future, forcing the present to remember, too hypertrophying the role of memory, compelling to collect the remnants of the past to overcome its isolation. This is in line with the concept of the British historian Eric Hobsbaum, who believes that modern societies need to restore, "invent" traditions and "connect" them to the common space of the past and present in order to capture at least part of the chaotic social life ${ }^{1 \mathrm{f}}$. The second reason for the seizure of memory is the powerful movement toward the liberation and emancipation of peoples, ethnicities, groups, individuals in the modern world, for whom this is a prerequisite for asserting one's identity and individuality. As Oswald Spengler noted, living a cultural life is a tense, passionate struggle with civilization processes that, by unifying one's personality is killing him: which does not take into account concepts and

9 Olick J. K. (2012) Figuracija pamjati: processo-reljacionnaja metodologija, illjustriruemaja na primere Germanii [Memory Configuration: Process Relational Methodology Illustrated with Germany]. Sociologicheskoe obozrenie [Sociological Review], vol. 11, no. 1, p. 55.

10 Nora P. (2005) Vsemirnoe torzhestvo pamyati [World Celebration of Remembrance]. Pamjat o vojne 60 let spustja: Rossija, Germanija, Evropa [The memory of the war 60 years later: Russia, Germany, Europe]. Moscow: Novoe literaturnoe obozrenie, pp. 391-403.

${ }^{11}$ Hobsbaum Je. (2000) Izobretenie tradicij [Invention of tradition]. Vestnik Evrazii [Bulletin of Eurasia], 1, pp. 47-62. 
systems. The glorious lunge (act $-\mathrm{T}$. H.) is more valuable here than the glorious conclusion" 12 .

Therefore, modern civilization is undergoing a reflection of its past in order to bring back to life those important meanings that lie in the cultural memory of humanity and which are powerfully actualized in a new, post-modern and post-modern space. After all, according to Ananda Kumaraswamy, in the world that modern philosophers dream of, even the names of ancient Greek or medieval treatises are a mystery, and their content comes from a completely different world - a world of tradition that is far from us much more than any astronomical worlds ${ }^{13}$.

Modern scholars have resorted to a new reading of ancient philosophy in accordance with the queries of our time ${ }^{14}$. Today, the awakening of historical memory, the recollection of the past, are key in society. These processes are in stark contrast to the beginning of the twentieth century when particular importance was attached to the future: the focus shifted from the "resent-day", the energy of which nourished the culture of modernity, to the "past present." From the apocalyptic myths of the birth of a "new man" and radical historical ruptures, through the deadly racial and class cleansing of the national-socialist and totalitarian regimes of the last century, there has been a shift, and, rather, an active search for previously "displaced components of the historical process." Today, any radical opposition is rejected for the sake of the possibility of dialogue with the past in the light of the future.

Thanks to the revival of memory, various theories and concepts are actualized as components of the world, in particular, European culture, which throughout its existence needs cultural and phenomenological reflection.

The analysis of contemporary sub specie art (at the point of view) of catharsis theory is complicated by the fact that it is almost impossible to cover all the forms, styles, genres, artistic directions, after all, the personalities that today make up the space of the arts. Therefore, it is

${ }^{12}$ Spengler O. (1993) Zakat Evropy. Ocherki morfologii mirovoj istorii [Sunset of Europe. Essays on the morphology of world history], vol. 1: Geshtalt $i$ dejstvitelnost [Gestalt and reality]. Moscow: Mysl.

13 Coomaraswamy A. K. (2011) Christian and Oriental Philosophy of Art. Mineola: Dover Publications.

${ }^{14}$ Nails D. (2019). Ljudi Platona. Prosopografija Platona i drugih sokratikov [People of Plato. Prosopography of Plato and other abbreviations]. Moscow: Grekolatinskij kabinet Ju. A. Shichalina. 
important to find out how the present and everyday life of societies, communities, and the individual are reflected in the arts and become participants in it. The specificity of the impact of art on humans, as we know, lies in the emotional reactions in the process of perceiving a work of art, and in this way is artistic communication. The highest manifestation of this influence is the phenomenon of catharsis, the interpretation of which is transformed in the context of those changes that take place in art from antiquity to our day.

Despite the fact that the concept of catharsis is common, it is necessary to specify its meaning in modern scientific discourse. As you know, Aristotle applied the theory of catharsis to the analysis of the phenomena of art and their role in society. His definition of the tragedy genre is based on the notion of catharsis as an emotional purification: "Tragedy is an imitation of action, serious and complete, with a certain volume, imitation by the speech adorned in each of its parts differently; by action rather than story that purifies because of pity and fear»» ${ }^{15}$.

What is the relevance of this aesthetic category in the cultural development of the 21 st century? In what ways is catharsis as a way of spiritual healing and healing of man, release from negative emotions, from anxiety, still remains the most important element of sensory culture today? How does catharsis, as the highest manifestation of the influence of art on the emotional sphere of man, transform into a situation "after postmodernism", that is, in the artistic culture of the early 21 st century?

The peculiarities of art development were influenced by the formation of a new sensual cultural type based on the new quality of the art world in the $21 \mathrm{st}$ century. Its characteristic feature is the experience of catharsis - the cleansing of the horrors of the past, which is experiencing the world "after Oswiecim" (T. Adorno). Thanks to the catharsis in the society of the age of "artisation" of everyday life, there is a rise of creative forces of culture. The catharsis of everyday life fits in with the concept of "fluid modernity" by Z. Bauman or a "flexible community" by J. Lipovetsky. It is about the readiness of the current mobile culture to constantly change, the inability to retain specific forms for a long time. The ideas of a prominent British sociologist, philosopher, most fully reflect the state of affairs of a modern society full of fear before the end of the world. This topic is mainstream for both research and works of art of recent years. In trying to answer the question of what the concept of

${ }^{15}$ Aristotel (1967) Poetyka [Poetics], (trans. Ten B.). Kyiv: Mystetstvo, p. 42. 
"end of the world" means and what role an individual plays in society, the scientist emphasizes "individuality" as an important characteristic of being in the culture of the late twentieth and early twentieth centuries.

In recent years, the centre of gravity has been transferred to the individual, who begins to perform those functions and solve those tasks that previously belonged to the sphere of activity of administrative, collective bodies. Along with the processes of globalization on a planetary scale, “... there is a process of "localization", of space fixation. Taken together, these interrelated processes dramatically differentiate the living conditions of populations across entire countries, regions, and diverse segments of the population." ${ }^{\text {"16 }}$ In social life, the principles of pluralism prevail, including the pluralism of cultures, the principles of democracy, and the individualization of subjects. This ensures the compatibility of different value systems, the right to be different. In the field of mobile culture, there is a chance to consume the same cultural products. "The concept of culture as an activity carried out by one part of the population in relation to another is superseded by the concept of a spontaneous process, which has no administrative or management centres, does not obey any master plans" ${ }^{\text {"17 }}$.

While in Kyiv, Z. Bauman participated in the Discussion Platform conference of the First Kyiv Biennale of Contemporary Art's project "Best Times, Worst Times. Renaissance and the Apocalypse in Contemporary Art". In one of his interviews, he drew attention to a situation that has developed in the world culture and is associated with a sense of the end of a certain period, its exhaustion and, at the same time, a lack of a sense of something new. It is the feeling of "empty space" (according to Peter Brooke), the completion of one world and the transition to a new reality, not yet understood, which we face in the form of a diverse continuum of new and new meanings, in which "... the usual

${ }^{16}$ Bauman Z. (2004) Globalizacija. Posledstvija dlja cheloveka i obshhestva [Globalization. Implications for man and society], (trans. Korobochkina M. L.). Moscow: Ves Mir, p. 11.

${ }^{17}$ Badyor D. (2012, April 19) Zigmunt Bauman: "Konets sveta - eto otsutstvie uverennosti v zavtrashnem dne" [Zygmunt Bauman: "The end of the world is a lack of confidence in the future"]. Retrieved from https://lb.ua/culture/2012/04/19/ 146824_zigmunt_bauman_konets_sveta-.html (accessed: 19.01.2019). 
and tried and tested means of effective action are not working already, and new tools and strategies have not yet been developed" 18 .

Reflections on catharsis as a category are directly brought into the realm of the aesthetic, where its history actually takes place. The sphere of contemporary art is a layer of non-classical (post-classical) culture. For the most part, it is not in line with the principle of mimesis, although it is capable of raising topical issues, involving the viewer, the listener, the reader in the dialogue. And here another problem arises because it is not always those who perceive art are ready for such a dialogue. Yes, there are negative reactions due to misunderstanding of "such art". Since aesthetics directly addresses the issues of perception of art, it is interesting to consider the transformations of classical concepts ("aesthetics", "aestheticization", "aesthetic") in connection with changes in art.

The problem of solid consumption, hedonistic personalization, related to the apotheosis of the cult of wish-fulfilment, thirst for entertainment and passive contemplation, which leads to the loss of landmarks, moral guidelines, and ultimately, cultural ethics, attracts the attention of philosophers. Consumer society needs a field of culture today that would be prepared to counter the logic of consumption, which would prevent the "purification", "catharsis" of society, including art for the sake of the future.

This universal approach makes it possible to combine all the arts in the interspecific space of artistic culture, which dominated the historical and philosophical reflections and formed the basis for contemporary cultural and philosophical and aesthetic knowledge. On the phenomenon of catharsis in art, in particular in the art of theatre, they are, in a new sense, conceived by contemporary researcher Kathy Chukhrov. It is important that the term "theatre" in this context does not mean theatre as one of the arts' kind. According to Kathy Chukhrov, the concept of "theatre" means a kind of mechanism, with the help of which we can speak of art as not a real practice. She introduces into the scientific discourse the concept of theatre as an object of art. The artist is not just living life as art, but trying to understand and rethink everything that goes on in life. He or she must have an ability to "live" the life of other

${ }^{18}$ Badyor D. (2012, April 19) Zigmunt Bauman: "Konets sveta - eto otsutstvie uverennosti v zavtrashnem dne" [Zygmunt Bauman: "The end of the world is a lack of confidence in the future"]. Retrieved from https://lb.ua/culture/2012/04/19/ 146824_zigmunt_bauman_konets_sveta-.html (accessed: 19.01.2019). 
people, must be ready to comprehend the universal (social, political, ethical, aesthetic, everyday).

Art, in this sense, is full of potentialities to encompass all available potentialities, which has led to a considerable number of languages of expression - from classical types to performative, collage, installation art. Such openness of art is peculiar to everyone. The introduction of the terms "theatre" and "performance" is connected with the definition of a new situation in art, which " $\ldots$ is somewhat on the verge of conditionally" objective "reality and its transformation. But this transformation is not self-sufficient, not self-reflective, as in modernism, and not total, as, in the classical avant-garde, it is as an event is put into the world and passes through a person, placing his or her life between being and over-being"19.

Here it is appropriate to turn to the ideas of Susan Sontag, an American researcher, the legislator of "radical fashion". In her work Against Interpretation, she argues that the culture of our time is characterized by a loss of ability to sense-perception, it is generated by excessive desires and overproduction, that interpretation is a revenge on the intellect of art, a manifestation of stifling reactivity, timidity, stagnation. For her more sensual vision, perception, sensation, in her opinion, it is necessary to give up hermeneutization and move to "eroticization of $\operatorname{art}{ }^{20}$. She believes that art is not obliged to be read as a text, because works of art are not just about telling something, commenting on something, arguing or denying it - they are already something. Art should evoke an experience, a sense of presence, a state of certain enchantment.

The problem of the new "erotica of art" resonates with the very topical theme of "outsidering", "otherwise", as the catharsis of everyday life experienced by a person "from there", becoming in the everyday life of society an object of humiliation, humiliation, and partly - violence. How lonely a person feels, which does not fit into the usual relationships of people in society, goes to the art of the era of "colour", "gender" and more. In her essay, Pornographic Imagination (1967), S. Sontag writes

${ }^{19}$ Chuhrov K. (2011) Byt i ispolnjat. Proekt teatra $v$ filosofskoj kritike iskusstva [To be and to fulfill. Theater project in philosophical criticism of art]. St. Petersburg: Izdatelstvo Evropeyskogo universiteta v Sankt-Peterburge, p. 30.

20 Sontag S. (2006) Proty interpretatsii [Against interpretation]. Proty interpretatsii ta inshi ese [Against interpretation and other essays], (trans. Dmytruk V.). Lviv: Kalvariia, pp. 10-21. 
about the need for the human being to "go beyond its borders," "to overcome one's personality," in particular, about the state of the artist in a world of non-classical (post-classical) culture: "As a free explorer of dangers, overbearing, the artist is entitled to differ in his behaviour from the majority, given the peculiarities of the vocation, he may, for example, be distinguished by an eccentric lifestyle, or may not. His real business the trophies of experience, objects and deeds that can ignite and enthral, and not only (as the former concepts have been attributed to the artist) to teach and have fun. It ignites, as a rule, one: a step into the dialectic of the disorder. He wants to do things disgusting, dark, incomprehensible, in a word - something that doesn't like (or doesn't like). But no matter how cruel the extremes of the artist impress his audience, his credentials and spiritual authority ultimately depend on the real or possible sensitivity of the public to those extremes, which he is trying himself..."21. The author is convinced that art draws from diverse human experience, including one based on various modes of personal transcendence. This "extended scale of experience" is an extraordinary power beyond good and evil, it is a test of catharsis beyond the mind.

At the same time, Dr Jennifer Wallace, a professor at Cambridge University, points out that the media and the public respond to tragic events, as the authors of a Greek tragedy do: instead of feeling horrified, they told about it as well as about tragic events. Therefore, in her opinion, the experience of catharsis is now more problematic. After all, according to Aristotle, the events depicted in the tragedy help to purify or ease the internal state of the viewer. That is, tragedy plays a certain moral function in society. Is it possible in modern life?"22 D. Wallace adds: "In an era of round-the-clock news and constant potential contact with tragedies around the world through the Internet, it may be paradoxically difficult to focus on the suffering that playwrights may have experienced and reproduced in the past. Does this even matter to us

${ }^{21}$ Sontag S. (1997) Pornographic imagination [Pornograficheskoe voobrazhenie]. Mysl kak strast. Izbrannye esse 1960-70-h godov [Thought is like passion. Selected essays of the 1960-70s], (ed. Dubina B., trans. Golysheva V.). Moscow: Russkoe fenomenologicheskoe obshhestvo, pp. 8-18.

22 Rozwadowski J. (2012, May 09) Reinventing tragedy in the modern age. Retrieved from https://www.cam.ac.uk/research/news/reinventing-tragedy-in-themodern-age (accessed: 19.01.2019). 
today? Is it the ability to create what can be called a "good tragedy", a sign of human civilization or a sign of a humane society?",23

Sinclair, professor of Contemporary Spanish Literature and Intellectual History, explains the over-interest of contemporary media in tragedies of other people, the transformation of information about disasters into everyday life by the fact that the line between awe and the horror that we often cross is too thin. "I am amazed that we take these stories on a daily basis. They cannot be considered catharsis, but constantly perceiving them is important to raise questions about our experience in general and our experience, which is difficult to face"24. She notes that Spanish writers of the twentieth century, including Federico Garcia Lorca, faced the need to reinvent tragedy for contemporary audiences, seeking to reconcile elements of Greek tragedy with contemporary realities, but perhaps avoiding catharsis. Moreover, many theorized in the early twentieth century that a new form was needed to replace tragedy. The goal, in her opinion, was to interrupt the processes of identification and/or catharsis, to release the viewer or even make him not feel, but to think about what was happening on stage, as well as the consequences of what he saw for himself.

The main difference in the aesthetic perception of classical and contemporary art lies in the fact that classical art is full of images and modern - ideas. T. Binkley considers the description to be used as a basic aid for understanding contemporary art by means of which one can access an idea conceived by the author of a work ${ }^{25}$. The author takes a controversial stance on aesthetics as a science. Her work, written in 1997, is actualized today as a revival of interest in the art of the 90s, with its "grassroots" aesthetics that began to acquire rights and emerge from the shadow of "outsider", "abnormal", "unacceptable".

${ }^{23}$ Rozwadowski J. (2012, May 09) Reinventing tragedy in the modern age. Retrieved from https://www.cam.ac.uk/research/news/reinventing-tragedy-in-themodern-age (accessed: 19.01.2019).

${ }^{24}$ Rozwadowski J. (2012, May 09) Reinventing tragedy in the modern age. Retrieved from https://www.cam.ac.uk/research/news/reinventing-tragedy-in-themodern-age (accessed: 19.01.2019).

${ }^{25}$ Binkli T. (1997) Protiv Jestetiki [Against Aesthetics]. Amerikanskaya filosofiya iskusstva. Osnovnye kontseptsii vtoroy poloviny XX veka - antiessentsializm, pertseptualizm, institutsionalizm [American Philosophy of Art. Basic Concepts of the Second Half of the 20th Century: Anti-Essentialism, Perceptualism, Institutionalism], (eds. Dzemidok B., Orlov B.). Ekaterinburg: Delovaja kniga. 
Creative events at the Arsenal of Art are full of similar meaning ("Flashback. Ukrainian Media Art of the 1990s", 2018), at PinchukArtCenter ("Red Book: Soviet Art of Lviv of the 1980s and 1990s" , 2018) and more. In particular, perhaps the most significant event in 2019 was the presentation of Olha Petrova's book "Art Kyiv in the 1990s: Reconstruction" held at the Khanenko Museum. As the researcher, philosopher, well-known artist, noted in her interview, the 90s was an extraordinary period in the history of Ukrainian art, when a talented galaxy of artists emerged who "... adopted a system of rebellion against everything, embraced voluntarism, nature of which I understand because it was contained in the socio-political climate of the time. Therefore, in the book, I describe the workshop art on a broad sociopolitical background, which is the interest of this work. After all, the 90s was a period of tough, though in some places invisible struggle between the old system, which did not want to leave, and the new one, which was not yet formed $\gg$.

In particular, T. Binkley, as the author of the work Against Aesthetics, does not support the view that aesthetics should be necessarily and primarily related to the philosophy of art. The term "aesthetics", coined by A. Baumgarten in the sense of "the science of perception", distinguished between aesthetic and abstract entities, that is, things that are sensually perceived and those that are perceived by the mind. T. Binkley, according to Kant, distinguishes the perception of aesthetic qualities not only concerning art but much more broadly - to human activity in general, in all its riches. Thus, for aesthetics, not only art objects are objects of study, but also aesthetic experiences and experiences in a wide variety of daily life areas.

Considering the impossibility of identifying the object of aesthetics and the object of art, T. Binkley characterizes contemporary art: "It liberates itself from aesthetic parameters and sometimes creates directly through ideas not mediated by aesthetic qualities. A work of art is a creation, and creation need not be an aesthetic object or even an object at

26 Andriivskyi uzviz svoho chasu buv ukrainskym Monmartrom dlia khudozhnykiv - Olha Petrova pro mystetstvo 90-kh rokiv [Andriyivsky Uzviz was once a Ukrainian Montmartre for artists - Olga Petrova on 90s art]. (2019, November 20). Retrieved from ukr.radio/news.html?newsID=91710 (accessed: 20.11.2019). 
all» ${ }^{27}$. So, we can say that contemporary art no longer exists in the classical dimension of the aesthetic, and therefore should not cause aesthetic experiences in the audience. Of course, the time during which art underwent a dramatic change and ceased to conform to the classical canons of mimesis is very short compared to the era when it developed according to classical mimetic principles. Only since the beginning of the twentieth century and until today it has undergone profound changes in the sphere of the aesthetic, in the perception of works of art (modern, post-modern, post-post-modern or contemporary...) and their evaluation and interpretation. The question here is how and in what way the classical idea of catharsis was transformed in the context of understanding the "tragic" today.

At the beginning of the twentieth century, Jean Baudrillard noted in the book Transparency of Evil that the boundaries of the aesthetic expanded significantly, encompassing all spheres of life: “... freeing from forms, lines, colours and aesthetic concepts, blending all cultures and all styles, our society has achieved universal aestheticization, all forms of culture ..." aesthetics. Accordingly, the experience of catharsis from communication with actual artistic creativity is complicated by philosophy, constant reflection of art about itself, because it requires intellectuallyinterpretative work, theorizing, and most importantly, a certain sensual detachment.

Due to the proliferation of performative, corporeal forms, contemporary art becomes too shocking, it is not capable of making a strong emotional impression, leading to catharsis, in its classical sense. Moreover, in the opinion of the philosopher, the use of traditional aesthetic concepts is generally ambiguous, and even inappropriate, because nowadays the only aesthetic canons by which the works of art can be compared and evaluated have been lost. Indeed, the aesthetic categories, which since antiquity had been the indestructible criteria in

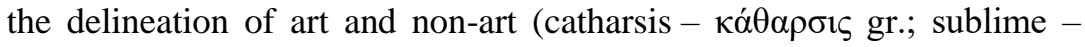

${ }^{27}$ Binkli T. (1997) Protiv Jestetiki [Against Aesthetics]. Amerikanskaya filosofiya iskusstva. Osnovnye kontseptsii vtoroy poloviny XX veka - antiessentsializm, pertseptualizm, institutsionalizm [American Philosophy of Art. Basic Concepts of the Second Half of the 20th Century: Anti-Essentialism, Perceptualism, Institutionalism], (eds. Dzemidok B., Orlov B.). Ekaterinburg: Delovaja kniga.

28 Baudrillard J. (2000) Prozrachnost zla [Transparency of evil], (trans. Ljubarskaja L., Markovskaja E.). Moscow: Dobrosvet. 


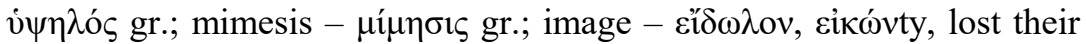
primary significance. Gradually the main feature of culture was the total aestheticization of the world, "even the most corrupt and obscene" (Bordriyar) acquires aesthetic features, embedded in the artistic sphere, becomes a cultural object.

Researchers point out that in the art of the XX - the beginning of the XXI centuries famous artists with their works consciously contributed to the fundamental break of the secret code of aesthetics. According to J. Ranier, the true aesthetic revolution can be considered the willingness of artists to show and glorify anyone and anything: "Such a phantasmagoric dimension of the true, belonging to the aesthetic mode of art, played an important role in the establishment of the critical paradigm of humanitarian humanities" 29 .

Touching on the topic of breaking the secret code of aesthetics, let us give the opinion of Dietmar Kamper, a sociologist, anthropologist, philosopher, one of the representatives of post-structuralist thought in Germany: "The only work of modern civilization was the constant production of artificiality, and therefore, aestheticization; modern culture is becoming a commodity that is unacceptable because art must be internally contradictory and not reproduce the consumer system. Only a person can choose the only possible option to move away, dissociate from the system and start to act proactively due to their virtuosity, not virtuality"30. For Kamper to be responsible means the ability and willingness for the artist at the moment of the highest danger to put himself at stake, raising a fundamental question for him.

The theme of catharsis as a warning and prevention of recurrence of the tragedy prompts us to return to our reflections on those events that determine our present and affect the future not only of our country but of the whole world. Thus, the TV movie "Chornobyl", according to IMDB, is recognized as the most popular series of all time (!), It provokes discussions, provokes passionate reactions. Nowadays tourists and journalists are eager to visit the exclusion zone. However, these tragic

${ }^{29}$ Rancière J. (2007) Razdeljaja chuvstvennoe [Sharing the sensual], (trans. Lapickij V., Shestakov A.). St. Petersburg: Izdatelstvo Evropeyskogo universiteta v Sankt-Peterburge.

30 Kamper D. (2010) Dvulikij Yanus media E`stetizacziya dejstvitel nosti. Vozmushenie chuvstv [Two-faced Janus Media. Aesthetization of reality. Outrage]. Telo. Nasilie. Bol [Body. Violence. Pain], (trans. Savchuk V.). St. Petersburg: Russkaja hristianskaja gumanitarnaja akademija, pp. 55-57. 
events have not only catastrophic man-made consequences - no less an ontological shock has emerged: a new ecology of culture has emerged, which contains a discourse on the collective trauma of humankind living after the "touch of death".

Recognizing that any analogy is rather conditional, let us recall in this context the fire that took place in April 2019 in the Cathedral of Notre Dame de Paris. It is known that in 1831 Victor Hugo wrote this novel of the same name to draw public attention to a landmark of national architecture that suffered so much during the Great French Revolution that it could be lost forever. But the publication of the novel, in the preface to which Hugo wrote, "One of my main goals is to inspire the nation with a love of our architecture," prompted the public to rebuild the cathedral. In the aftermath of the 2019 fire, culture, art, France and the world took on such a mission, apart from the media and the Internet.

In this way, trauma is closely linked to the problem of truth or what is called the "crisis of truth", thus raising the question: how can we have access to our historical experience today? Therefore, there is no one-sizefits-all approach to listening, listening to traumatic experiences, and stories about it. Their exclusivity requires a wide variety of reflections in psychoanalytic and psycholinguistics, in philosophy and cultural studies, in political science and history, as well as in the arts in general. The need for complex reflection is generated by the originality of the event itself as an exceptional, tragic experience that goes beyond human understanding.

Ukrainian art (nota bene! - here inevitable parallels with the novel of the French classic) draws attention to Ukraine, its history and contemporary problems due to the artistic reproduction of the Chernobyl tragedy (other tragedies in modern and post-modern history) in its "nonidentity". The means of art reveal a rigorous, uncompromising understanding of the phenomena and events that Ukraine is experiencing, entering a new, post-imperial, post-Soviet phase of its history. Society is painfully undergoing a long process of escaping the captivity of centuries-old colonization of mentality. The new generation of Ukrainian artists is creating a modern national space, full of socio-cultural reflection, aimed at reflecting on "one's" and "other's", centre and periphery, dominant and subordinate, individual and social, monomulticultural, authentic and globalized, certifying the culture state of the third millennium: the entry into the world of "sub specie".

Since the Chernobyl catastrophe, so many significant historical events and socio-cultural shifts have taken place in Ukraine that it is now 
possible to speak of a completely different reality than that associated with the end of the twentieth century as the time of the fall of totalitarian regimes

The processes experienced by Ukrainian society since the end of 2013 make it possible to speak about their collective character since they have caused tectonic shifts in the recent history of Ukraine: Revolution of Dignity, execution of Maidan participants, subsequently - annexation of Crimea, military aggression in the Donbas, proclamation of DNR and LNR (The Donetsk People's Republic and the Luhansk People's Republic) an economic and political crisis that triggered a new cultural upheaval, manifested in the will of the people in the 2019 presidential and parliamentary elections. What is rather polemical, with pain, aware of the difficult political experience of the Maidan, the Ukrainian historian A. Plachonin called it as the end of the "era of self-pity"

The uniqueness of T. Hundorova's study "Transit Culture", mentioned by us, is that despite its transient and extremely rapid sociopolitical and cultural changes, her ideas do not become obsolete, but become even more relevant, contribute to the understanding of the situation in which Ukraine found itself. Maidan and the long conflict in the Donbas. Particularly valuable for understanding the current Ukrainian reality are the researcher's remarks on "resentment" as a factor in the formation of post-colonial and post-totalitarian social (subjective) consciousness. Despite the literal meaning of the term (French ressentiment - outrage, indignation), it is more complex and contradictory in its meaning. The phenomenon of resentment arises in a situation of extreme tension between a sense of self-esteem and, at the same time, a hatred of all the enemy, which is perceived as the cause and source of damage, loss, powerlessness, and ultimately, inferiority. Such a condition, as the researcher points out, "... is the critical instance where effect takes the form of resentment. The discharge leads either to pathology or turns into a complex but productive cultural therapy" ${ }^{\text {, }}$. That is the experience of catharsis, we will add.

Taking into account the events that Ukrainian society is experiencing today, the experience of the Maidan fits into the much broader context of post-communist trauma, moreover, into the discursive field of trauma

31 Hundorova T. (2013) Vid avtora [From the author]. Tranzytna kultura. Symptomy postkolonialnoi travmy [Transit culture. Symptoms of postcolonial trauma]. Kyiv: Hrani-T. 
studies, which for most researchers is a paradigm characteristic of the late twentieth and early twentieth centuries' culture. Thus, modern researchers emphasize the importance of "discourses" - the "testimonies" of all those who survived, suffered, or fell victim to "see" and "hear" the tragedy. It is from the moment of the written-proclaimed testimony, whether it belongs to an individual or a group of people, or takes the form of a work of art, that society begins to work with the consequences of its traumatic experience. Therefore, the concept of "traumatic character of culture" is expanding to the whole world, especially modern researchers emphasize sensitivity to the topic of violence of non-western parts of the world, in which the most catastrophic events are happening in recent times.

It turns out that Ukraine's experience from the Maidan to the annexation of Crimea and the war on Donbas is consonant with world history of the beginning of the 21st century. It highlights the threatening conflicts in the new era of humanity already. Moreover, in the socialized world, there is a unique opportunity to evoke the feeling of historical experience simultaneity in different nations, societies and categories of people, a feeling of empathy that will form a special type of shared social memory.

Turning to 2019, it should be noted that for the Ukrainian society after surviving the Maidans, after the last presidential election, probably the most characteristic is the "next morning syndrome". In the history of Ukraine, the problem of trust and mutual understanding between citizens becomes actual again, that is, the opportunity arises to profess common values as the basis of community culture and identity. Social ambivalence, as a simultaneous commitment of people to opposing, sometimes incompatible values, characterizes a transitional society.

The long shadow of the past and, at the same time, the irreversibility of the historic progress towards freedom, are the poles of tension that determine the path to the formation of a renewed Ukrainian nation, they will contribute to the unification of the west and the east, the north and the south, past and present Ukraine. According to the apt statement of the Ukrainian cultural scientist and political scientist Taras Wozniak, it is the tragic events of recent years that present the reality of the present, with the help of which the cathartic experience we can look into our future.

Another factor of dependence and inability to forget is the incredible strain of the spirit, the fascinating atmosphere of the significance of what is happening because this is what has become, for many, the "top of life". In general, it is the state of any "excessive" or grieving subject who 
is unable to overcome the melancholy dependency on survived experience or love. Exactly these poles of worldview tragically combined in time and space two superfluous personalities, two talented artists - Vasily Spivak, an opera singer who left his successful creative life in Paris to fight and die for Ukraine, and Leonid Kanter, the coauthor of the documentary about him - "Myth". This name is short for Mephistopheles, this is the call sign of the hero - a reference to the favourite character of the singer from the opera "Faust". The director Leonid Kanter, in collaboration with I. Yasny, avoided frank mythmaking, favouring moving thoughts about V. Slipak, the nature of victims and wars in general. It is a philosophical, deeply humanistic and multifaceted message about a maximalist personality. "The Myth" begins and ends with Parisian children listening to their teacher in the classroom, who is reading a book by Gianni Rodari. Gelsomino, with his charming voice, which people could not help overhear, was able to save the Land of Liars by expelling the autocrat ruler. Vasily Slipak was killed, but Ukraine has not yet been rescued. His voice continues to be heard, he is heard ... However, life is carrying out its tragic recursion: there is a war in Donbas, there is a confrontation between politicians, parties, people ... Meanwhile, in the personally built art-khutor (so to speak, in the other, already Ukrainian "Neverland") Leonid Kanter at the age of 36 , committed suicide...

"Listening", attentive listening to one's historical experience and the history of it, about their exceptionality requires a multifaceted response, complex thinking, including artistic. Since the experience tests the limits of our understanding.

Taking into account the consequences of the tragic events in the history of Ukraine that took place during the end of the XX - beginning of the XXI centuries, relying on interdisciplinary studies of the concept of trauma, on different types of narratives about collective trauma the experience gained by Ukrainian society at the beginning of the 21 st century it is possible to claim that they had a significant impact on the cultural processes of modern times. This gave an opportunity to show the development of Ukrainian culture of this period as a reflection of the deep traumatic processes that determine not only its present but also affect the cultural progress of mankind. The symbolic extension and correlation of the Ukrainian people experience with the world transgressive processes universalizes it as one that is essential for global understanding in the world, which is possible only if one is able and willing to listen and hear. 


\section{CONCLUSIONS}

Therefore, the main purpose of contemporary art today is to "raise questions", problems that are important but not articulated in everyday life. Thus, the categories of the aesthetic force to analyze the sociocultural logic of development of modern society. After all, the art which we can consider relevant, effective, seeks to reproduce, replicate social, focusing on problems in modern society. Thanks to this reflection, the identification of the individual and the society in a particular cultural type occurs. As a theatre is a mediator between the event and the individual, so the culture becomes the mediator between the history and the individual, the history and the society. It fills us with what we could not naturally obtain. In experiencing this fullness, there is a selfpromotion of a society to a new cultural form. It can be argued that every nation, every society from time to time undergoes the revival of its culture, tests the cultural genes that have shaped its uniqueness, reflected in the uniqueness of its centuries-old fate. A non-reflective society is doomed to degradation.

\section{SUMMARY}

The section describes a wide range of interdisciplinary studies on the concept of trauma and includes a theoretical toolkit for multi- and interdisciplinary trauma studies to analyze different types of narratives about collective traumatic experiences acquired by Ukrainian society in the early 21 st century. The sensitivity of society to the topic of violence, its theorization and detailed categorization, or vice versa - the rejection of this in cases of extreme violence that destroys any category, increase with the deepening of the modern tragic experience of humanity. The prolonged impact of traumatic experiences on the individual, as well as on the collective consciousness, gives rise to feelings of fear and vulnerability at the individual and collective levels. As a result of the Chernobyl disaster, Ukraine emerged as a deeply traumatized social space that signalled to the world about a new state: entering the zone of a new culture of the humanity of the third millennium.

At the beginning of the new millennium, the cultural memory of humankind is actualized. Today, the awakening of historical memory and the recollection of the past are key in society's life. This contrasts sharply with the beginning of the twentieth century when particular importance was attached to the future: the focus shifted from the "present to present", the energy of which was nourished by the culture of modernity, to the "past present." The specificity of the art impact on a 
person is emotional reactions in the process of perceiving a work of art, and in this way is artistic communication. The highest manifestation of this influence is the phenomenon of catharsis, the interpretation of which is transformed in the context of those changes that take place in art from antiquity to our day. The peculiarities of art development were influenced by the formation of a new sensual cultural type based on the new quality of the art world in the 21 st century. Its characteristic feature is the experience of catharsis as a "purification" of the horrors of the past.

\section{REFERENCES}

1. Alexander J. (2013) The Meanings of Social Life: cultural sociology [Smysly soczialnoj zhizni: kultursocziologiya], (trans. G. K. Olkhovikova). Moscow: Praksis. (in Russian)

2. Andriivskyi uzviz svoho chasu buv ukrainskym Monmartrom dlia khudozhnykiv - Olha Petrova pro mystetstvo 90-kh rokiv [Andriyivsky Uzviz was once a Ukrainian Montmartre for artists - Olga Petrova on 90s art]. (2019, November 20). Retrieved from ukr.radio/news.html? newsID=91710 (accessed: 20.11 .2019$)$.

3. Aristotel (1967) Poetyka [Poetics], (trans. Ten B.). Kyiv: Mystetstvo. (in Ukrainian)

4. Badyor D. (2012, April 19) Zigmunt Bauman: "Konets sveta - eto otsutstvie uverennosti v zavtrashnem dne" [Zygmunt Bauman: "The end of the world is a lack of confidence in the future"]. Retrieved from https://lb.ua/culture/2012/04/19/146824_zigmunt_bauman_konets_sveta.html (accessed: 19.01.2019).

5. Baudrillard J. (2000) Prozrachnost zla [Transparency of evil], (trans. Ljubarskaja L., Markovskaja E.). Moscow: Dobrosvet. (in Russian)

6. Bauman Z. (2004) Globalizacija. Posledstvija dlja cheloveka $i$ obshhestva [Globalization. Implications for man and society], (trans. Korobochkina M. L.). Moscow: Ves Mir. (in Russian)

7. Binkli T. (1997) Protiv Jestetiki [Against Aesthetics]. Amerikanskaya filosofiya iskusstva. Osnovnye kontseptsii vtoroy poloviny XX veka - antiessentsializm, pertseptualizm, institutsionalizm [American Philosophy of Art. Basic Concepts of the Second Half of the 20th Century: Anti-Essentialism, Perceptualism, Institutionalism], (eds. Dzemidok B., Orlov B.). Ekaterinburg: Delovaja kniga.

8. Caruth C. (ed.) (1995) Trauma: Explorations in Memory. Baltimore: Johns Hopkins University Press. (in English) 
9. Chuhrov K. (2011) Byt $i$ ispolnjat. Proekt teatra $v$ filosofskoj kritike iskusstva [To be and to fulfill. Theater project in philosophical criticism of art]. St. Petersburg: Izdatelstvo Evropeyskogo universiteta v Sankt-Peterburge. (in Russian)

10. Coomaraswamy A. K. (2011) Christian and Oriental Philosophy of Art. Mineola: Dover Publications. (in English)

11. Einarsson E. (2019, June 06) Chernobyl review: "Stunning and shattering in equal measure". Retrieved from https://www.gamesradar.com/chernobyl-hbo-review/ (accessed: 19.06.2019).

12. Hobsbaum Je. (2000) Izobretenie tradicij [Invention of tradition]. Vestnik Evrazii [Bulletin of Eurasia], 1, pp. 47-62.

13. Hundorova T. (2013) Vid avtora [From the author]. Tranzytna kultura. Symptomy postkolonialnoi travmy [Transit culture. Symptoms of postcolonial trauma]. Kyiv: Hrani-T.

14. Kamper D. (2010) Dvulikij Yanus media E`stetizacziya dejstvitel'nosti. Vozmushhenie chuvstv [Two-faced Janus Media. Aesthetization of reality. Outrage]. Telo. Nasilie. Bol [Body. Violence. Pain], (trans. Savchuk V.). St. Petersburg: Russkaja hristianskaja gumanitarnaja akademija, pp. 55-57.

15. Lifton R. (2005) Tehnologija „promyvki Mozgov”: Psihologija totalitarizma [Brainwashing Technology: The Psychology of Totalitarianism]. St. Petersburg: Prajm-Evroznak. (in Russian)

16. Luckhurst R. (2008) The Trauma Question. New York: Routledge. (in English)

17. Nails D. (2019). Ljudi Platona. Prosopografija Platona i drugih sokratikov [People of Plato. Prosopography of Plato and other abbreviations]. Moscow: Greko-latinskij kabinet Ju. A. Shichalina. (in Russian)

18. Neal A. G. (2005) National Trauma and Collective Memory: Extraordinary Events in the American Experience. Armonk, New York: Routledge. (in English)

19. Nora P. (2005) Vsemirnoe torzhestvo pamyati [World Celebration of Remembrance]. Pamjat o vojne 60 let spustja: Rossija, Germanija, Evropa [The memory of the war 60 years later: Russia, Germany, Europe]. Moscow: Novoe literaturnoe obozrenie, pp. 391-403.

20. Olick J. K. (2012) Figuracija pamjati: processo-reljacionnaja metodologija, illjustriruemaja na primere Germanii [Memory Configuration: Process Relational Methodology Illustrated with 
Germany]. Sociologicheskoe obozrenie [Sociological Review], vol. 11, no. 1, pp. 40-74.

21. Rancière J. (2007) Razdeljaja chuvstvennoe [Sharing the sensual], (trans. Lapickij V., Shestakov A.). St. Petersburg: Izdatelstvo Evropeyskogo universiteta v Sankt-Peterburge. (in Russian)

22. Rozwadowski J. (2012, May 09) Reinventing tragedy in the modern age. Retrieved from https://www.cam.ac.uk/research/news/ reinventing-tragedy-in-the-modern-age (accessed: 19.01.2019).

23. Sontag S. (1997) Pornographic imagination [Pornograficheskoe voobrazhenie]. Mysl kak strast. Izbrannye esse 1960-70-h godov [Thought is like passion. Selected essays of the 1960-70s], (ed. Dubina B., trans. Golysheva V.). Moscow: Russkoe fenomenologicheskoe obshhestvo, pp. 8-18.

24. Sontag S. (2006) Proty interpretatsii [Against interpretation]. Proty interpretatsii ta inshi ese [Against interpretation and other essays], (trans. Dmytruk V.). Lviv: Kalvariia, pp. 10-21.

25. Spengler O. (1993) Zakat Evropy. Ocherki morfologii mirovoj istorii [Sunset of Europe. Essays on the morphology of world history], vol. 1: Geshtalt i dejstvitelnost [Gestalt and reality]. Moscow: Mysl. (in Russian)

Information about the author: Humeniuk Tetiana, orcid.org/0000-0001-9210-6424 Doctor of Philosophy, Professor Kyiv National University of Culture and Arts 36, Ye. Konovaltsia Str., Kyiv, 01133, Ukraine 